\title{
Geology
}

\section{Isotopic evidence for changes in the zinc cycle during Oceanic Anoxic Event 2 (Late Cretaceous) \\ --Manuscript Draft--}

\begin{tabular}{|c|c|}
\hline Manuscript Number: & G40226R1 \\
\hline Full Title: & $\begin{array}{l}\text { Isotopic evidence for changes in the zinc cycle during Oceanic Anoxic Event } 2 \text { (Late } \\
\text { Cretaceous) }\end{array}$ \\
\hline Article Type: & Article \\
\hline \multicolumn{2}{|l|}{$\begin{array}{l}\text { Corresponding Author Secondary } \\
\text { Information: }\end{array}$} \\
\hline First Author: & Tim Sweere \\
\hline \multicolumn{2}{|l|}{ First Author Secondary Information: } \\
\hline \multirow[t]{5}{*}{ Order of Authors: } & Tim Sweere \\
\hline & Alexander J. Dickson \\
\hline & Hugh C. Jenkyns \\
\hline & Don Porcelli \\
\hline & Maya Elrick \\
\hline Abstract: & $\begin{array}{l}\text { Widespread deposition of organic-rich shales during the Late Cretaceous Oceanic } \\
\text { Anoxic Event } 2 \text { (OAE } 2, ~ 94 \mathrm{Ma} \text { ) occurred during a period of significant global } \\
\text { palaeoenvironmental and geochemical change. It has been proposed that an increase } \\
\text { in nutrient input to the ocean during OAE } 2 \text { was the key mechanism that generated and } \\
\text { sustained high rates of organic-matter burial over timescales of } 103-105 \text { years. Zn is a } \\
\text { bio-essential micronutrient and the proportion of } \mathrm{Zn} \text { burial in oxic sediments relative to } \\
\text { burial in organic-rich continental margin sediments is reflected in its seawater isotope } \\
\text { composition. The first Zn-isotope records dating from the Cretaceous are presented } \\
\text { here from three coeval carbonate successions: two from Europe (southern England } \\
\text { and southern Italy) and one from Central America (southern Mexico). The new data } \\
\text { show reproducible stratigraphic Zn-isotope patterns in spatially and lithologically } \\
\text { diverse carbonate successions. Excursions to lower Zn-isotope values may be linked } \\
\text { to the input of magmatic zinc, changes in the proportion of Zn burial into organic-rich } \\
\text { sediments, and the liberation of previously buried Zn during an episode of widespread } \\
\text { seafloor re-oxygenation during OAE } 2 \text { (the Plenus Cold Event). }\end{array}$ \\
\hline
\end{tabular}


Publisher: GSA

Journal: GEOL: Geology

DOI:10.1130/G40226.1

1 Isotopic evidence for changes in the zinc cycle during

2 Oceanic Anoxic Event 2 (Late Cretaceous)

3 Tim C. Sweere ${ }^{1}$, Alexander J. Dickson ${ }^{1}$, Hugh C. Jenkyns ${ }^{1}$, Don Porcelli ${ }^{1}$, Maya

4 Elrick $^{2}$, Sander H.J.M. van den Boorn ${ }^{3}$, and Gideon M. Henderson ${ }^{1}$

$5{ }^{1}$ Department of Earth Sciences, University of Oxford, South Parks Road, Oxford OXI

$63 A N, U K$

$7 \quad{ }^{2}$ Department of Earth and Planetary Sciences, MSCO3-2040, 1 University of New

8 Mexico, Albuquerque, New Mexico 87131, USA

$9 \quad{ }^{3}$ Shell Projects and Technology, Kessler Park, 2288 GS Rijswijk, Netherlands

10 ABSTRACT

11 Widespread deposition of organic-rich shales during the Late Cretaceous Oceanic

12 Anoxic Event 2 (OAE 2, 94 Ma) occurred during a period of significant global

13 palaeoenvironmental and geochemical change. It has been proposed that an increase in

14 nutrient input to the ocean during OAE 2 was the key mechanism that generated and

15 sustained high rates of organic-matter burial over timescales of $10^{3}-10^{5}$ years. $\mathrm{Zn}$ is a

16 bio-essential micronutrient and the proportion of $\mathrm{Zn}$ burial in oxic sediments relative to

17 burial in organic-rich continental margin sediments is reflected in its seawater isotope

18 composition. The first $\mathrm{Zn}$-isotope records dating from the Cretaceous are presented here

19 from three coeval carbonate successions: two from Europe (southern England and

20 southern Italy) and one from Central America (southern Mexico). The new data show

21 reproducible stratigraphic Zn-isotope patterns in spatially and lithologically diverse

22 carbonate successions. Excursions to lower Zn-isotope values may be linked to the input 
Publisher: GSA

Journal: GEOL: Geology

DOI:10.1130/G40226.1

23 of magmatic zinc, changes in the proportion of $\mathrm{Zn}$ burial into organic-rich sediments, and

24 the liberation of previously buried Zn during an episode of widespread seafloor re-

25 oxygenation during OAE 2 (the Plenus Cold Event).

\section{INTRODUCTION}

27 Several distinct intervals of widespread deposition of organic-rich black shales

28 occurred during some of the most extreme perturbations to global climate and

29 oceanography of the Phanerozoic Eon. Mesozoic Oceanic Anoxic Events (OAEs) have

30 been associated with rapid warming, the spread of low-oxygen marine environments and

31 perturbations to floral and faunal diversity and biogeochemical cycles (e.g., Jenkyns,

32 2010).

33 For the Late Cretaceous OAE 2 (Cenomanian-Turonian, 94 Ma), geochemical

34 models indicate that the initiation and maintenance of high rates of organic-matter

35 production required an increase in oceanic nutrient inventories (Monteiro et al., 2012).

36 Indeed, proxy evidence suggests that widespread volcanism may have caused an

37 increased supply of nutrients to the ocean, either through basalt-seawater interaction, or

38 indirectly by warming-induced intensification of (silicate) weathering of mafic and felsic

39 rocks and by an intensified hydrological cycle (e.g., Turgeon and Creaser, 2008; Jenkyns

40 et al., 2017). Although these observations constitute evidence for potential changes in

41 nutrient inventories, direct evidence for the availability of bio-limiting nutrients in the

42 oceans is currently limited, largely due to a lack of applicable proxies.

43 The major nutrients phosphorus and nitrogen may have been relatively abundant

44 due to regeneration of the former from anoxic sediments (Mort et al. 2007 and references

45 therein) and increased fixation of the latter by abundant diazotrophic cyanobacteria 
Publisher: GSA

Journal: GEOL: Geology

DOI:10.1130/G40226.1

46 utilizing atmospheric di-nitrogen in nitrate-depleted seawater (Kuypers et al., 2004).

47 Extensive burial of organic matter during OAEs may have triggered a biotic response as

48 redox-sensitive bio-limiting metals were removed from global seawater (e.g., Owens et

49 al., 2016). Assessing the importance of feedback mechanisms between trace-metal

50 availability, biotic response, and the carbon cycle requires the use of appropriate proxies.

51 During times of major global change, such as the OAEs, proxies that enable

52 reconstruction of ocean chemistry at a regional or global scale are particularly valuable.

\section{Zn-Isotope Systematics}

54 Although not limiting to overall productivity in the modern ocean, $\mathrm{Zn}$ is

55 fundamental for many life processes and its concentration is reduced to near zero by

56 biological activity in the surface ocean (e.g., Wyatt et al. 2014). Zn has a present-day

57 oceanic residence time of $\sim 11,000$ years (Little et al., 2014). The Zn-isotope composition

58 of today's deep ocean is homogeneous $\left(\delta^{66} \mathrm{Zn}=\sim 0.5 \%\right.$ o $\pm 0.14 ; 2 \mathrm{SD}$, Conway and John,

59 2014) and is isotopically heavier than the bulk silicate Earth and sources of Zn to the

60 ocean such as rivers, dust, hydrothermal springs, and benthic inputs (Little et al., 2014;

61 Vance et al., 2016 and references therein). Reported oxic sinks of Zn (e.g., Fe-Mn

62 oxyhydroxides) are isotopically heavier than inputs and deep-ocean values $\left(\delta^{66} \mathrm{Zn}>\sim 0.5\right)$

63 (e.g., Little et al., 2014). Organic-rich continental-margin sediments are so far the only

64 documented removal sink of isotopically light $\mathrm{Zn}$ from the oceans (Little et al., 2016).

65 The low $\delta^{66} \mathrm{Zn}$ values observed for these sediments may be the result of non-quantitative

66 removal of $\mathrm{Zn}$ in sulfides, or due to scavenging of isotopically heavy $\mathrm{Zn}$ just below the

67 surface ocean, resulting in low $\delta^{66} \mathrm{Zn}$ values in the photic zone where organic material is

68 generated (Little et al., 2016; Vance et al., 2016; John et al., 2017). 
Publisher: GSA

Journal: GEOL: Geology

DOI:10.1130/G40226.1

69 Alteration of the input and output fluxes of $\mathrm{Zn}$ to and from the ocean in concert

70 with global environmental changes might thus be expected to have impacted the marine

71 cycling of $\mathrm{Zn}$. A relative increase in the removal flux of $\mathrm{Zn}$ from seawater into organic-

72 rich continental margin sediments compared to $\mathrm{Zn}$ burial in oxic sediments would cause a

73 shift toward higher $\delta^{66} \mathrm{Zn}$ values in the global ocean and vice versa; a relative increase in

74 the input of isotopically light $\mathrm{Zn}$ from hydrothermal sources or remobilized from margin

75 sediments can result in lower $\delta^{66} \mathrm{Zn}$ values in the global ocean (Fig. 1).

76 Modern surface-ocean $\delta^{66} \mathrm{Zn}$ values are generally lower than the deep ocean by

$77 \sim 0.5 \%$, but show a high degree of spatial variability $\left(\delta^{66} \mathrm{Zn}=-1.1\right.$ to $+0.9 \%$, Conway

78 and John, 2014). These variations are likely caused by biological uptake of Zn,

79 scavenging of isotopically heavy $\mathrm{Zn}$, and the lateral or vertical advection of water masses

80 (e.g. Conway and John, 2014). Pelagic and shallow-water carbonates have previously

81 been used to reconstruct upper-ocean $\mathrm{Zn}$-isotope compositions for intervals of

82 Quaternary, Neoproterozoic, and Late Permian-Early Triassic time (Pichat et al., 2003;

83 Kunzmann et al., 2013; Liu et al., 2017). The use of such deposits as archives for past

84 global seawater chemistry requires consideration of $\mathrm{Zn}$-isotope effects caused by the

85 balance of inputs and outputs to the local upper ocean, superimposed on slower changes

86 in the global mass balance of $\mathrm{Zn}$ that might lead to changes in homogenous deep-water

87 composition.

\section{MATERIAL AND METHODS}

89 Data are presented for three marine carbonate successions that span the

90 Cenomanian-Turonian boundary interval: the nannofossil-rich English chalk exposed

91 near Eastbourne, southern England; shallow-water platform carbonates exposed near Raia 
Publisher: GSA

Journal: GEOL: Geology

DOI:10.1130/G40226.1

92 del Pedale, Southern Apennines, Italy; and the Barranca el Cañón limestone section in the

93 state of Guerrero, southern Mexico (Fig. 2). The Eastbourne chalk, comprising

94 coccoliths, planktonic foraminifera and some macrofossils, formed primarily in the photic

95 zone, and was deposited in waters that were probably no deeper than 600m (Hancock,

96 1975). The platform carbonates found at the other two locations were primarily formed

97 from skeletal material in shallower (i.e., a few tens of meters or less) waters (Parente et

98 al., 2008; Elrick et al., 2009). The well-studied Eastbourne sample set is used as the

99 primary data set here because it has a stratigraphically expanded and well-documented

100 OAE 2 succession, containing sediments with little diagenetic alteration and relatively

101 low amounts of detrital and/or organic matter (TOC < 0.26 wt.\%) (Hancock, 1975;

102 Tsikos et al., 2004). The other two outcrops have well-established carbon-isotope and/or

103 bio-stratigraphic profiles that allow direct comparison with the Eastbourne succession,

104 but may have been compromised as geochemical archives due to their more variable

105 original carbonate mineralogy (aragonite and calcite) and greater degree of lithification

106 (Parente et al., 2008; Elrick et al., 2009, SI).

107 Zn-isotope data were measured relative to the IRMM 3702 standard on carbonates

108 that were selectively leached from bulk rocks and reported as $\delta^{66} \mathrm{Zn}$ after adding $+0.28 \%$

109 to allow direct comparison with previously published data ( $\left.\delta^{66} \mathrm{Zn}_{\text {JMC-Lyon }}\right)$. Further

110 analytical details are provided in the Supplementary Information (SI).

\section{RESULTS}

$112 \delta^{66} \mathrm{Zn}$ values average $1.06 \pm 0.38 \%$ (2 s.d., $\left.\mathrm{n}=28\right), 1.14 \pm 0.51 \%$ (2 s.d., $\mathrm{n}=$

113 22), and $0.89 \pm 0.49 \%$ (2 s.d., $\mathrm{n}=14)$ for the Eastbourne, Raia del Pedale and Barranca

114 el Cańón data sets respectively (Fig. 3), and are comparable to data from other 
Publisher: GSA

Journal: GEOL: Geology

DOI:10.1130/G40226.1

115 palaeoenvironmental studies on biogenic carbonates $(\sim 0.91 \%$, Pichat et al., 2003;

$116 \sim 0.75 \%$, Liu et al., 2017). The most striking features of the primary Eastbourne data are

117 two $\sim 0.5 \%$ o shifts toward lower $\delta^{66} \mathrm{Zn}$ values, marked ' $\mathrm{A}$ ' and ' $\mathrm{B}$ ' in Figure 3, separated

118 by an increase toward higher values. A similar shift to lower $\delta^{66} \mathrm{Zn}$ values is also seen in

119 the Raia del Pedale data at Event B. Isotope data from Barranca el Cańón are too sparse

120 and scattered to resolve clear trends, despite their rather similar average values to those at

121 other sites. Events $\mathrm{A}$ and $\mathrm{B}$ in $\delta^{66} \mathrm{Zn}$ correspond with recognized features of the $\delta^{13} \mathrm{C}$

122 stratigraphy of OAE 2 (Tsikos et al., 2004), namely the first increase in $\delta^{13} \mathrm{C}$ at the onset

123 of OAE 2 (which occurs after the start of Event $\mathrm{A}$ ) and the decrease in $\delta^{13} \mathrm{C}$ that

124 corresponds with the Plenus Cold Event (Event B).

$125 \mathrm{Zn} / \mathrm{Ca}$ values average $15 \pm 21(2$ s.d., $\mathrm{n}=48), 3.6 \pm 7.1(2$ s.d., $\mathrm{n}=21)$, and $14 \pm$

$12638(2$ s.d., $\mathrm{n}=46) \mu \mathrm{mol} / \mathrm{mol}$ for the Eastbourne, Raia del Pedale and Barranca el Cańón

127 data sets respectively (Fig. 3), and are comparable to the range in $\mathrm{Zn} / \mathrm{Ca}$ observed in

128 marine calcifiers (e.g., $\mathrm{Zn} / \mathrm{Ca}$ in benthic foraminifera: $3.3 \mu \mathrm{mol} / \mathrm{mol}$, Marchitto et al.,

129 2000; planktonic foraminifera: $35 \mu \mathrm{mol} / \mathrm{mol}$, Boyle, 1981). Marked stratigraphic

130 features in $\mathrm{Zn} / \mathrm{Ca}$ include an increase in $\mathrm{Zn} / \mathrm{Ca}$ in Eastbourne during Event $\mathrm{B}$ and

131 increases in Barranca el Cańón during Event B and the Early Turonian.

$132 \mathrm{Al}$ and $\mathrm{Mn}$ abundances in the leachates are used to assess the leaching of clays

133 and ferromanganese coatings for the Eastbourne and Barranca el Cańón sample sets.

134 These data suggest that stratigraphic trends in $\mathrm{Zn} / \mathrm{Ca}$ and $\delta^{66} \mathrm{Zn}$ are not the result of

135 leaching of $\mathrm{Zn}$ from clays or ferromanganese coatings, as no significant change in $\mathrm{Al}$ or

136 Mn content is associated with changes in $\delta^{66} \mathrm{Zn}$ (see SI).

\section{DISCUSSION}


Publisher: GSA

Journal: GEOL: Geology

DOI:10.1130/G40226.1

\section{Carbonates as an Archive for $\delta^{\mathbf{6}} \mathbf{Z n}$}

139 Differences between $\delta^{66} \mathrm{Zn}$ observed in this study, other carbonate studies, and the

140 modern ocean might reflect changes in the $\delta^{66} \mathrm{Zn}$ value of the global oceans through time.

141 However, interpretation is not straightforward because carbonate sediments are likely to

142 record shallow-water seawater compositions, which can vary significantly relative to the

143 deep ocean composition. Carbonate $\delta^{66} \mathrm{Zn}$ values that are considerably higher than

144 modern deep-waters $(0.5 \%)$ are also difficult to explain, because surface seawater ( 0 -

$1451000 \mathrm{~m})$ generally has lower $\delta^{66} \mathrm{Zn}$ than deep-water. This difference may suggest a

146 significant systematic isotope fractionation $(>+0.4 \%$ ) during incorporation of $\mathrm{Zn}$ into

147 marine carbonates or adsorbed to calcite surfaces, as has been suggested by Dong and

148 Wasylenki (2016). Rather than seeking to quantify this offset more precisely, we focus on

149 relative changes in the $\delta^{66} \mathrm{Zn}$ values within our records.

\section{Surface-Ocean Processes and Spatial Patterns}

151 For large parts of the Cenomanian-Turonian interval, $\delta^{66} \mathrm{Zn}$ values between the

152 three sites are similar, which is surprising considering the heterogeneity of dissolved

$153 \delta^{66} \mathrm{Zn}$ in the modern surface ocean. During such intervals, the fraction of $\mathrm{Zn}$ removed

154 from the surface ocean must be similar at the three sites. Common stratigraphic variations

155 in $\delta^{66} \mathrm{Zn}$ (i.e., Event B), which approach amplitudes of $\sim 0.5 \%$, might possibly have been

156 caused by near-synchronous changes in the expression of local processes on upper-ocean

157 Zn cycling at each location (e.g., a change in the removal rate from near-surface waters

158 by biological fixation or adsorption). However, such a process seems unlikely

159 considering the different $\mathrm{Zn} / \mathrm{Ca}$ patterns between the cores during this time interval.

160 Whereas the upper part of the Event B record at Eastbourne is associated with higher $\mathrm{Zn}$ 
Publisher: GSA

Journal: GEOL: Geology

DOI:10.1130/G40226.1

161 abundances, values at Raia del Pedale are relatively constant, excluding the notion of

162 local upper-ocean $\mathrm{Zn}$-inventory changes as a likely explanation for the observed $\delta^{66} \mathrm{Zn}$

163 values at both sites. Hence, the common Zn-isotope stratigraphic fluctuations at

164 Eastbourne and Raia del Pedale more plausibly record changes in the whole-ocean

165 isotopic composition of $\mathrm{Zn}$, and thus represent changes in its global cycling during $\mathrm{OAE}$

1662.

167 Zn-Cycle Perturbation in Relation to a Magmatic Episode-Event A

168 Osmium-isotope data suggest that increased basalt-seawater interaction persisted

169 throughout much of the OAE 2 (Turgeon and Creaser, 2008; Du Vivier et al., 2015), a

170 phenomenon that likely favored the elevated input of dissolved trace metals into the

171 ocean (e.g., Elrick et al., 2009). The initial shift of Os isotopes to unradiogenic values,

172 like that of $\delta^{66} \mathrm{Zn}$, pre-dates the onset of the positive carbon-isotope excursion,

173 conventionally taken to record the beginning of OAE 2. This shift in Os isotopes has been

174 related to the input of unradiogenic Os from volcanism or some other form of basalt-

175 seawater interaction involving one or more Large Igneous Provinces (Turgeon and

176 Creaser, 2008; Du Vivier et al., 2015; Jenkyns et al., 2017).

177 The first drop in $\delta^{66} \mathrm{Zn}$ (Event A, Fig. 3) may represent a particularly strong pulse

178 of isotopically light $\mathrm{Zn}$ to the ocean from hydrothermal fluids or low-temperature

179 reactions between seawater and mafic rocks (cf, Liu et al., 2017). A rapid Zn input from

180 this source may have created heterogeneities in the isotopic composition of surface

181 waters, which could explain the variable magnitude of the negative $\mathrm{Zn}$-isotope excursions

182 at Raia del Pedale and Eastbourne. This observation would directly link the onset of a

183 magmatic episode with ocean nutrification as a trigger for increased carbon burial during 
Publisher: GSA

Journal: GEOL: Geology

DOI:10.1130/G40226.1

184 the initial phase of OAE 2. Increased $\mathrm{Zn}$ burial into globally expanding organic-rich

185 sediments shortly after Event A (and the initial unradiogenic Os-isotope shift), can

186 explain the pattern of gradually increasing $\mathrm{Zn}$-isotope compositions, despite consistently

187 unradiogenic osmium-isotope seawater values during this interval.

188 Zinc-Cycle Perturbation during the Plenus Cold Event—Event B

189 The second drop toward lower $\delta^{66} \mathrm{Zn}$ values (Event B, Fig. 3) occurred during the

190 Plenus Cold Event, which was associated with re-oxygenation in many locations and had

191 a major effect on ocean chemistry (Jenkyns et al., 2017; Clarkson et al., 2018). A relative

192 decrease in the size of organic-rich continental margin sinks for isotopically light $\mathrm{Zn}$ as a

193 result of improved bottom-water oxygenation explains lower $\delta^{66} \mathrm{Zn}$ values observed at

194 both Eastbourne and Raia del Pedale. An additional factor driving the observed Zn-

195 isotope variations during the Plenus Cold Event and the elevated $\mathrm{Zn} / \mathrm{Ca}$ ratios in

196 Eastbourne during this time interval may have been the release of isotopically light $\mathrm{Zn}$

197 from organic-rich continental-margin sediments as a result of an increase in (aerobic)

198 biodegradation of organic matter and sulphides, as observed in parts of the modern ocean

199 (Conway and John, 2014). Elevated concentrations of conservative redox-sensitive trace

200 metals (e.g., Mo, U) observed previously at both Eastbourne and Raia del Pedale have

201 been linked to the re-oxidation of previously buried organic-rich sediments (Jenkyns et

202 al., 2017). By contrast, the absence of elevated Zn/Ca ratios at Raia del Pedale (Fig. 3) is

203 probably due to the very shallow (less than a few tens of meters) setting of this site and

204 the high efficiency of Zn removal that is likely to have occurred from surface waters in

205 extremely oligotrophic conditions. 
Publisher: GSA

Journal: GEOL: Geology

DOI:10.1130/G40226.1

The Plenus Cold Event has been associated with biotic turnover and changes in

207 the distribution of phytoplankton (Parente et al., 2008; Van Helmond et al., 2016 and

208 references therein). The new $\mathrm{Zn}$-isotope data suggest that, in addition to oxygenation and

209 cooling, perturbations to micronutrient cycles might have played a role in driving these

210 paleoecological changes. A perturbation to the Zn cycle during the Plenus Cold Event, as

211 inferred from relatively light $\mathrm{Zn}$-isotope compositions and elevated $\mathrm{Zn} / \mathrm{Ca}$ ratios in

212 Eastbourne and Barranca el Cańón, can be directly correlated with the extinction of larger

213 benthic foraminifera, as recorded in the Southern Apennines of Italy. These K-strategists

214 were adapted to nutrient-poor conditions and therefore suffered from the switch to more

215 nutrient-rich conditions during the Plenus Cold Event (Parente et al., 2008). Surface-

216 ocean nutrification during the Plenus Cold Event was inferred previously from the

217 distribution of foraminifera alone. The data presented here support this model of a

218 perturbation to the (micro)nutrient cycle.

\section{CONCLUSIONS}

220 Zn-isotope trends in marine carbonates from England, Italy and Mexico

221 demonstrate perturbations to the zinc cycle during the Cenomanian-Turonian interval,

222 with isotopically light $\mathrm{Zn}$-isotope compositions observed just prior to the onset of OAE 2

223 and during the Plenus Cold Event. This work constitutes the first isotopic evidence for

224 changes in the Zn cycle during the Cretaceous and supports the hypothesis that ocean

225 nutrification was important in driving widespread and intense organic-carbon burial at the

226 onset of OAE 2. Specifically, the correlation between $\mathrm{Zn}$-isotope variations and the

227 extinction of benthic foraminifera recorded in platform carbonates of the Southern

228 Apennines is consistent with a link between the abundance of micronutrients and the 
Publisher: GSA

Journal: GEOL: Geology

DOI:10.1130/G40226.1

229 extinction of marine fauna adapted to oligo- and mesotrophic conditions. Given the

230 reproducibility of stratigraphic Zn-isotope patterns in spatially and lithologically diverse

231 carbonate successions, this proxy may be an important tool for reconstructing the ocean

232 redox and nutrient chemistry in ancient oceans.

233 ACKNOWLEDGMENTS

234 We gratefully acknowledge Shell for research funding and Seth John and two anonymous

235 reviewers for thoughtful comments.

\section{REFERENCES CITED}

237 Boyle, E.A., 1981, Cadmium, zinc, copper, and barium in foraminifera tests: Earth and

238 Planetary Science Letters, v. 53, p. 11-35, https://doi.org/10.1016/0012-

$239 \quad 821 \times(81) 90022-4$.

240 Conway, T.M., and John, S.G., 2014, The biogeochemical cycling of zinc and zinc

241 isotopes in the North Atlantic Ocean: Global Biogeochemical Cycles, v. 28, p. 1111-

242 1128, https://doi.org/10.1002/2014GB004862.

243 Clarkson, M.O., Stirling, C.H., Jenkyns, H.C., Dickson, A.J., Porcelli, D., Moy, C.M.,

244 Pogge von Strandmann, P.A.E., Cooke, I.R., and Lenton, T.M., 2018, Uranium

245 isotope evidence for two episodes of deoxygenation during Oceanic Anoxic Event 2:

246 Proceedings of the National Academy of Sciences of the United States of America,

247 (in press).

248 Dong, S., and Wasylenki, L.E., 2016, Zinc isotope fractionation during adsorption to

249 calcite at high and low ionic strength: Chemical Geology, v. 447, p. 70-78,

$250 \quad$ https://doi.org/10.1016/j.chemgeo.2016.10.031. 
Publisher: GSA

Journal: GEOL: Geology

DOI:10.1130/G40226.1

251 Du Vivier, A., Selby, D., Condon, D., Takashima, R., and Nishi, H., 2015, Pacific

$252 \quad{ }^{187} \mathrm{Os} /{ }^{188} \mathrm{Os}$ isotope chemistry and $\mathrm{U}-\mathrm{Pb}$ geochronology: Synchroneity of global Os

253 isotope change across OAE 2: Earth and Planetary Science Letters, v. 428, p. 204-

$254 \quad$ 216, https://doi.org/10.1016/j.epsl.2015.07.020.

255 Elrick, M., Molina-Garza, R., Duncan, R., and Snow, L., 2009, C-isotope stratigraphy

256 and paleoenvironmental changes across OAE2 (mid-Cretaceous) from shallow-water

257 platform carbonates of southern Mexico: Earth and Planetary Science Letters, v. 277,

258 p. 295-306, https://doi.org/10.1016/j.epsl.2008.10.020.

259 Hancock, J.M., 1975, The petrology of the Chalk: Proceedings of the Geologists'

260 Association, v. 86, p. 499-535.

261 Jenkyns, H. C., 2010, Geochemistry of oceanic anoxic events: Geochemistry,

262 Geophysics, Geosystems, v. 11, Q03004, doi:20.1029/2009GC002788.

263 Jenkyns, H.C., Dickson, A.J., Ruhl, M., and Van Den Boorn, S.H., 2017, Basalt-seawater

264 interaction, the Plenus Cold Event, enhanced weathering and geochemical change:

265 Deconstructing Oceanic Anoxic Event 2 (Cenomanian-Turonian, Late Cretaceous):

266 Sedimentology, v. 64, p. 16-43, https://doi.org/10.1111/sed.12305.

267 John, S.G., Kunzmann, M., Townsend, E.J., and Rosenber, A.D., 2017, Zinc and

268 cadmium stable isotopes in the geological record: A case study from the post-

269 snowball Earth Nuccaleena cap dolostone: Palaeogeography, Palaeoclimatology,

270 Palaeoecology, v. 466, p. 202-208, https://doi.org/10.1016/j.palaeo.2016.11.003.

271 Kunzmann, M., Halverson, G.P., Sossi, P.A., Raub, T.D., Payne, J.L., and Kirby, J.,

272 2013, $\mathrm{Zn}$ isotope evidence for immediate resumption of primary productivity after

273 snowball Earth: Geology, v. 41, p. 27-30, https://doi.org/10.1130/G33422.1. 
Publisher: GSA

Journal: GEOL: Geology

DOI:10.1130/G40226.1

274 Kuypers, M.M., van Breugel, Y., Schouten, S., Erba, E., and Damsté, J.S.S., 2004, N2-

275 fixing cyanobacteria supplied nutrient $\mathrm{N}$ for Cretaceous oceanic anoxic events:

276 Geology, v. 32, p. 853-856, https://doi.org/10.1130/G20458.1.

277 Little, S., Vance, D., Walker-Brown, C., and Landing, W., 2014, The oceanic mass

278 balance of copper and zinc isotopes, investigated by analysis of their inputs, and

279 outputs to ferromanganese oxide sediments: Geochimica et Cosmochimica Acta,

$280 \quad$ v. 125 , p. 673-693, https://doi.org/10.1016/j.gca.2013.07.046.

281 Little, S.H., Vance, D., McManus, J., and Severmann, S., 2016, Key role of continental

282 margin sediments in the oceanic mass balance of $\mathrm{Zn}$ and $\mathrm{Zn}$ isotopes: Geology, v. 44,

283 p. 207-210, https://doi.org/10.1130/G37493.1.

284 Liu, S.-A., Wu, H., Shen, S.-Z., Jiang, G., Zhang, S., Lv, Y., Zhang, H., and Li, S., 2017,

285 Zinc isotope evidence for intensive magmatism immediately before the end-Permian

286 mass extinction: Geology, v. 45, p. 343-346, https://doi.org/10.1130/G38644.1.

287 Marchitto, T.M., Curry, W.B., and Oppo, D.W., 2000, Zinc concentrations in benthic

288 foraminifera reflect seawater chemistry: Paleoceanography, v. 15, p. 299-306,

289 https://doi.org/10.1029/1999PA000420.

290 Monteiro, F., Pancost, R., Ridgwell, A., and Donnadieu, Y., 2012, Nutrients as the

291 dominant control on the spread of anoxia and euxinia across the

292 Cenomanian-Turonian oceanic anoxic event (OAE2): Model-data comparison:

293 Paleoceanography, v. 27, p. PA4209, https://doi.org/10.1029/2012PA002351.

294 Mort, H.P., Adatte, T., Föllmi, K.B., Keller, G., Steinmann, P., Matera, V., Berner, Z.,

295 and Stüben, D., 2007, Phosphorus and the roles of productivity and nutrient 
Publisher: GSA

Journal: GEOL: Geology

DOI:10.1130/G40226.1

recycling during oceanic anoxic event 2: Geology, v. 35, p. 483-486,

297 https://doi.org/10.1130/G23475A.1.

298 Owens, J.D., Gill, B. C., Jenkyns, H.C., Bates, S.M., Severmann, S., Kuypers, M. M. M.,

299 Woodfine, R. G., and Lyons, T.W., 2013, Sulfur isotopes track the global extent and

300 dynamics of euxinia during Cretaceous Oceanic Anoxic Event 2: Proceedings of the

301 National Academy of Sciences of the United States of America, v. 110 (46), p.

302 18407-18412, doi: 10.1073/pnas.1305304110.

303 Owens, J.D., Reinhard, C.T., Rohrssen, M., Love, G.D., and Lyons, T.W., 2016,

304 Empirical links between trace metal cycling and marine microbial ecology during a

305 large perturbation to Earth's carbon cycle: Earth and Planetary Science Letters,

306 v. 449, p. 407-417, https://doi.org/10.1016/j.epsl.2016.05.046.

307 Parente, M., Frijia, G., Di Lucia, M., Jenkyns, H.C., Woodfine, R.G., and Baroncini, F.,

3082008 , Stepwise extinction of larger foraminifers at the Cenomanian-Turonian

309 boundary: A shallow-water perspective on nutrient fluctuations during Oceanic

310 Anoxic Event 2 (Bonarelli Event): Geology, v. 36, p. 715-718,

311 https://doi.org/10.1130/G24893A.1.

312 Pichat, S., Douchet, C., and Albarède, F., 2003, Zinc isotope variations in deep-sea

313 carbonates from the eastern equatorial Pacific over the last $175 \mathrm{ka}$ : Earth and

314 Planetary Science Letters, v. 210, p. 167-178, https://doi.org/10.1016/S0012-

$315 \quad 821 X(03) 00106-7$.

316 Tsikos, H., Jenkyns, H., Walsworth-Bell, B., Petrizzo, M., Forster, A., Kolonic, S., Erba,

317 E., Silva, I.P., Baas, M., and Wagner, T., 2004, Carbon-isotope stratigraphy recorded

318 by the Cenomanian-Turonian Oceanic Anoxic Event: Correlation and implications 
Publisher: GSA

Journal: GEOL: Geology

DOI:10.1130/G40226.1

319 based on three key localities: Journal of the Geological Society, v. 161, p. 711-719,

320 https://doi.org/10.1144/0016-764903-077.

321 Turgeon, S.C., and Creaser, R.A., 2008, Cretaceous oceanic anoxic event 2 triggered by

322 massive magmatic episode: Nature, v. 454, p. 323-326,

323 https://doi.org/10.1038/nature07076.

324 Van Helmond, N.A., Sluijs, A., Papadomanolaki, N.M., Plint, A.G., Gröcke, D.R.,

325 Pearce, M.A., Eldrett, J.S., Trabucho-Alexandre, J., Walaszczyk, I., and

326 Schootbrugge, B.d., 2016, Equatorward phytoplankton migration during a cold spell

327 within the Late Cretaceous super-greenhouse: Biogeosciences, v. 13, p. 2859-2872,

328 https://doi.org/10.5194/bg-13-2859-2016.

329 Vance, D., Little, S.H., Archer, C., Cameron, V., Andersen, M.B., Rijkenberg, M.J., and

330 Lyons, T.W., 2016, The oceanic budgets of nickel and zinc isotopes: The importance

331 of sulfidic environments as illustrated by the Black Sea: Philosophical

332 Transansactions of the Royal Society A, v. 374, p. 20150294,

333 https://doi.org/10.1098/rsta.2015.0294.

334 Wyatt, N.J., Milne, A., Woodward, E.M.S., Rees, A.P., Browning, T.J., Bouman, H.A., 335 Worsfold, P.J., and Lohan, M.C., 2014, Biogeochemical cycling of dissolved zinc 336 along the Geotraces South Atlantic transect GA10 at $40^{\circ} \mathrm{S}$ : Global Biogeochemical

337 Cycles, v. 28, p. 44-56, https://doi.org/10.1002/2013GB004637.

339 FIGURE CAPTIONS

340 
Publisher: GSA

Journal: GEOL: Geology

DOI:10.1130/G40226.1

341 Figure 1. Schematic representation of $\mathrm{Zn}$-isotope systematics based on data compiled by

342 Little et al. (2014, 2016) and Vance et al. (2016). The sizes of the circles represent

343 relative flux sizes, the numbers their isotopic composition in \%o. The diagrams indicate

344 end-member steady-state oceanographic conditions.

346 Figure 2. Paleogeographical reconstruction for the Cenomanian-Turonian boundary

347 interval, modified from Owens et al. (2013) with approximate sample locations.

349 Figure $3 . \mathrm{Zn}$-isotope $\left(\delta^{66} \mathrm{Zn}\right)$ stratigraphy of Cenomanian-Turonian carbonates. The Raia

350 del Pedale and Barranca el Cañón data were converted to the Eastbourne depth scale by

351 tying key inflection points from the published carbon-isotope stratigraphies available for

352 each location (Tsikos et al., 2004; Parente et al., 2008; Elrick et al. 2009, SI). Chalk

353 intervals are shown as blank, marls as stippled (Tsikos et al., 2004). A and B highlight

354 decreases toward lower $\delta^{66} \mathrm{Zn}$ values. The horizontal black line marks the extinction level

355 of larger foraminifera as recorded in the Raia del Pedale section (Parente et al., 2008).

356 The vertical orange band represents the time interval associated with unradiogenic Os-

357 isotope seawater compositions in the global ocean (Jenkyns et al., 2017).

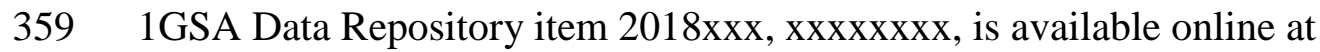

360 http://www.geosociety.org/datarepository/2018/ or on request from

361 editing@geosociety.org. 


\section{Isotopically light deep ocean}

- High volcanic/hydrothermal input

- Light Zn remobilized from continental margin sediments - Sparse organic-rich continental margin sinks for isotopically light $Z n$ - Abundant oxic sinks for isotopically heavy Zn

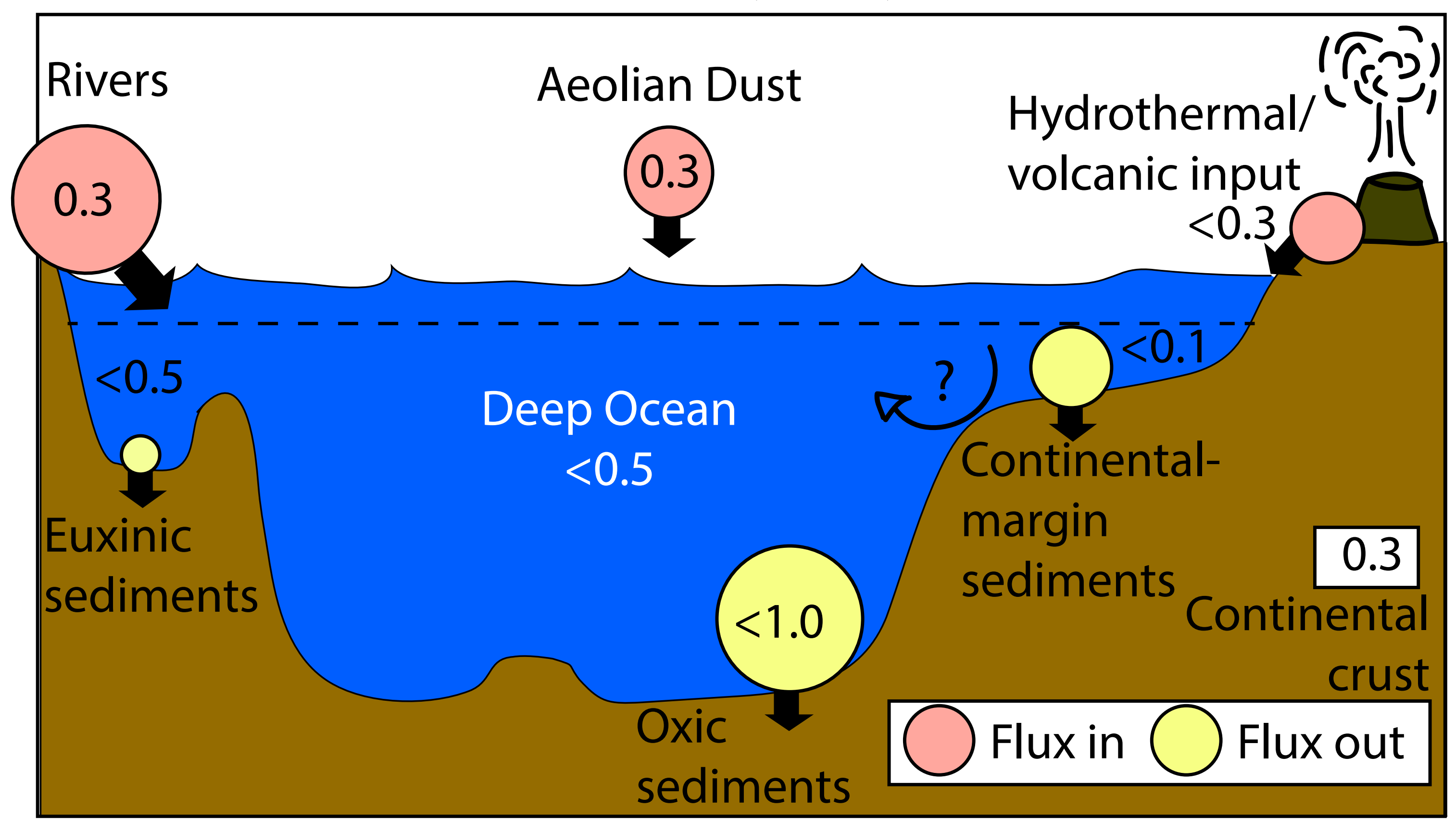

Isotopically heavy deep ocean

- Low volcanic/hydrothermal input

- Mostly organic-rich continental margin sinks for isotopically light Zn

- Sparse oxic sinks for isotopically heavy Zn

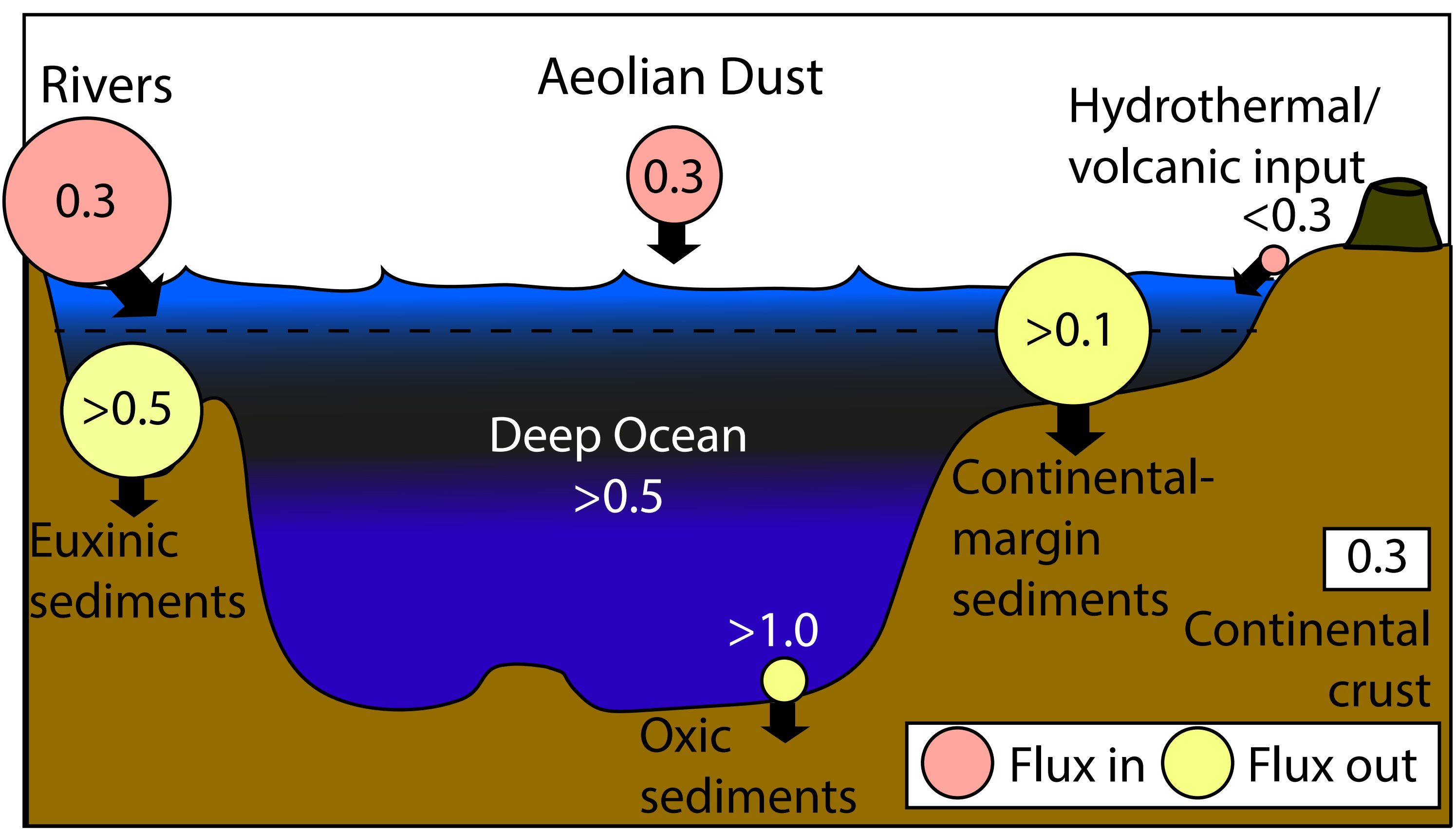




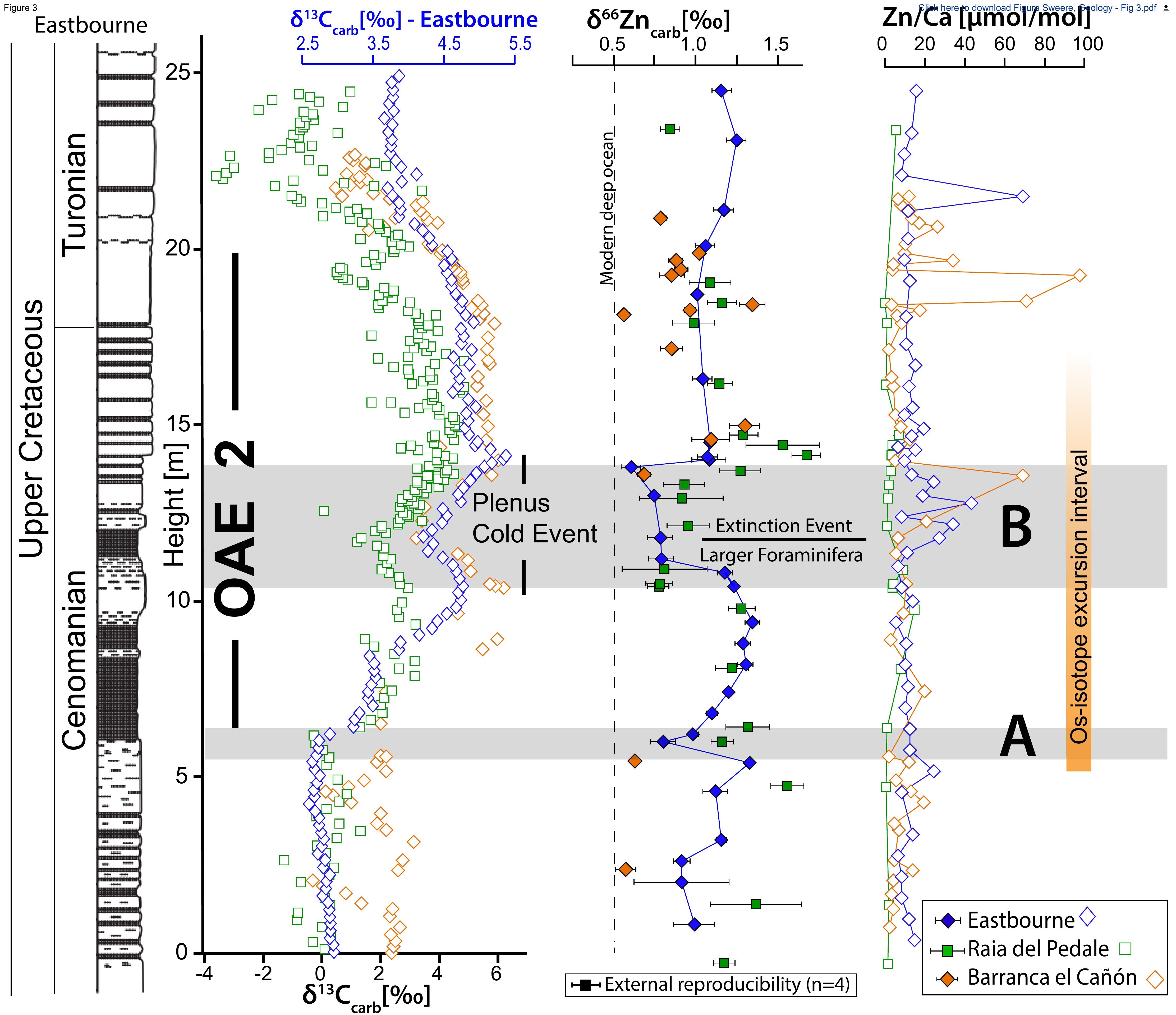




\section{SUPPLEMENTARY INFORMATION}

Isotopic evidence for changes in the zinc cycle during Oceanic Anoxic Event 2 (Late Cretaceous) - Sweere et al.

\section{Analytical methods - $\delta^{66} \mathbf{Z n}$}

Samples were selected based on visual inspection and available data (e.g. \%TOC, \% insoluble, elemental abundances) to minimize contribution from any non-carbonate sources of $\mathrm{Zn}$. A leaching procedure similar to previously established methods was used to preferentially dissolve the carbonate fraction for these samples (Pichat et al., 2003, Kunzmann et al., 2013, Liu et al., 2017). 0.5-1 g of crushed material was treated with $\mathrm{KCl}$ and then rinsed and sonicated in Milli-Q ultrapure water to remove the exchangeable fraction (Tessier et al., 1979). The carbonate phase was selectively dissolved using $0.5 \mathrm{M}$ acetic acid, which was added slowly in $0.5 \mathrm{ml}$ aliquots to allow the dissolving carbonate to act as a $\mathrm{pH}$ buffer. After centrifugation to remove undissolved phases, an aliquot of the supernatant was analyzed for $\mathrm{Zn}$ abundances on a ThermoFisher ELEMENT 2 ICP-MS or, using isotope dilution, on a MC-ICP-MS at the University of Oxford. Another aliquot was then spiked with a ${ }^{67} \mathrm{Zn}-{ }^{64} \mathrm{Zn}$ double spike to obtain a spike:sample ratio of $\sim 1.4$ (Rudge et al., 2009).

Zn was separated using AG1X-8 anion exchange resin (200-400 mesh) loaded onto shrink-fit Teflon columns with a resin bed of $200 \mu \mathrm{L}$. Samples were loaded in $0.6 \mathrm{ml} \mathrm{1M} \mathrm{HF} \mathrm{/} \mathrm{0.5M} \mathrm{HCl,} \mathrm{and} \mathrm{major-element} \mathrm{cations} \mathrm{and} \mathrm{isobaric} \mathrm{interferences} \mathrm{(} \mathrm{Ni}$ and $\mathrm{Ba}$ ) were subsequently eluted with a further $1.5 \mathrm{ml} 1 \mathrm{M} \mathrm{HF} / 0.5 \mathrm{M} \mathrm{HCl}$, followed by $1.5 \mathrm{ml}$ of $4 \mathrm{M} \mathrm{HCl}$. $\mathrm{Zn}$ was then eluted with $2.2 \mathrm{ml} 0.5 \mathrm{M} \mathrm{HF}$. The column procedure was repeated to ensure maximum removal of $\mathrm{Ni}$ and $\mathrm{Ba}$ from the sample matrix. All chemistry was done in Teflon using distilled acids.

Stable-isotope measurements were performed using a Nu Plasma MC-ICP-MS in medium-resolution mode, on $120 \mathrm{ppb}$ (spike plus sample) Zn solutions. Zn-isotope 
compositions were measured relative to the IRMM 3702 standard (Moeller et al., 2012) and then expressed relative to AA-ETH Zürich $\mathrm{Zn}+0.28 \%$, as suggested by Archer et al. (2017), as AA-ETH Zürich Zn and IRMM 3702 are isotopically indistinguishable.

$$
\begin{gathered}
\delta^{66} \mathrm{Zn}=\left({ }^{66} \mathrm{Zn} /{ }^{64} \mathrm{Zn}_{\text {sample }}-{ }^{66} \mathrm{Zn} /{ }^{64} \mathrm{Zn}_{\text {IRMM }}\right) * 1000 \\
{ }^{66} \mathrm{Zn} /{ }^{64} \mathrm{Zn}_{\text {IRMM }}
\end{gathered}
$$

Error bars represent the propagated uncertainties based on 2 standard errors of the counting statistics and reproducibility of bracketing standards. External reproducibility was estimated by analysis of reference material BCS-CRM 393 (ECRM 752-1) with a $\delta^{66} \mathrm{Zn}$ composition of $0.75 \pm 0.09 \%(2 \mathrm{SD}, \mathrm{n}=4)$ and secondary isotope standard 'London Zn' with a $\delta^{66} \mathrm{Zn}$ of $0.09 \pm 0.08 \%$ ( $2 \mathrm{SD}, \mathrm{n}=$ 19), which is in agreement with published values (Moeller et al., 2012). Procedural blanks were determined for every batch using isotope dilution and were always $<2 \mathrm{ng}$ $(\mathrm{n}=9)$, which is $<1 \%$ of all $\mathrm{Zn}$ processed.

\section{Analytical methods - Zn/Ca}

Sample preparation for $\mathrm{Zn} / \mathrm{Ca}$ and $\mathrm{Zn} / \mathrm{Al}$ analyses were largely similar to the method outlined above for the $\mathrm{Zn}$-isotope analysis, with exclusion of the first $\mathrm{KCl}$ stage to remove the exchangeable fraction. Elemental abundances were analyzed on a ThermoFisher ELEMENT 2 ICP-MS at the University of Oxford. For some samples (Raia del Pedale), Zn abundances were below detection limit using ICP-MS analysis so $\mathrm{Zn} / \mathrm{Ca}$ values for this site were measured by isotope dilution by MC-ICP-MS. Where Ca concentration data were not available on the same sample aliquot for these samples, Ca was estimated using the sample weight before leaching and assuming a 
Ca concentration of $40 \%$ in the leachable fraction. These samples were given an estimated error bar (of $40 \%$ ) relative to the $\mathrm{Zn} / \mathrm{Ca}$ ratio associated with this estimate.

\section{Contribution of $\mathrm{Zn}$ from detrital minerals}

Pelagic and platform carbonates are expected to record Zn-isotope values in the upper part of the water column. However, the high abundance of $\mathrm{Zn}$ in detrital minerals means that liberation of $\mathrm{Zn}$ from non-carbonate phases during chemical preparation may obscure these primary trends. $\mathrm{Zn} / \mathrm{Al}$ ratios can be used to estimate the proportion of $\mathrm{Zn}$ leached from detrital minerals relative to total leached $\mathrm{Zn}$, where $\mathrm{Al}$ is taken to represent the amount of leaching from detrital minerals.

$\mathrm{Zn} / \mathrm{Al}$ ratios were measured by ThermoFisher ELEMENT 2 ICP-MS at the University of Oxford during the same analysis as the $\mathrm{Zn} / \mathrm{Ca}$ measurements, and are therefore for samples leached without $\mathrm{KCl}$ treatment to remove the exchangeable fraction. This leach therefore differs slightly from that used for the $\mathrm{Zn}$-isotope samples, but the amount of $\mathrm{Zn}$ in the exchangeable fraction is very low (Tessier et al., 1979) so this small difference in leaching methods is not expected to influence significantly the estimated proportion of $\mathrm{Zn}$ associated with detrital minerals. Stratigraphic $\mathrm{Zn} / \mathrm{Al}$ patterns do not show signs of increased leaching from detrital minerals (i.e. drops to lower $\mathrm{Zn} / \mathrm{Al}$ values) during intervals of lithological or $\delta^{66} \mathrm{Zn}$ change, which suggests the leaching of $\mathrm{Zn}$ from detrital minerals does not impact stratigraphic $\delta^{66} \mathrm{Zn}$ patterns (Figure 1).

If leaching of $\mathrm{Zn}$ and $\mathrm{Al}$ from detrital minerals is assumed to be proportional, these abundances can be used to estimate the amount of zinc liberated from the lithogenic component as a fraction of total leached zinc using:

$$
\mathrm{X}_{\text {lith }}=\left[(\mathrm{Zn} / \mathrm{Al})_{\text {lith }} /(\mathrm{Zn} / \mathrm{Al})_{\mathrm{carb}}\right] * 100 \%
$$


with $\mathrm{X}_{\text {lith }}$ being the lithogenic (detrital) fraction of $\mathrm{Zn}$ in the leachate, $(\mathrm{Zn} / \mathrm{Al})_{\text {lith }}$ based on the average composition of upper continental crust (Rudnick and Gao, 2003), and $(\mathrm{Zn} / \mathrm{Al})_{\text {carb }}$ the measured concentrations in the leachate. Following this approach, the maximum $\mathrm{X}_{\text {lith }}$ found are 0.13 and $0.51 \%$ for Eastbourne and Barranca el Cañón sections, respectively. Given this low detrital component, no attempt to correct carbonate $\delta^{66} \mathrm{Zn}$ values for detrital input was made.

\section{Contribution of $\mathrm{Zn}$ from ferromanganese coatings}

Like previous Zn-isotope studies on carbonates (Pichat et al., 2003, Kunzmann et al., 2013, Liu et al., 2017), the applied method for the selective dissolution of the carbonate fraction does not include a reductive cleaning step prior to the dissolution of carbonate minerals. Such techniques are used in other studies to remove potential contamination from ferromanganese coatings (e.g. Clarkson et al., 2018). The exclusion of this cleaning procedure allows better comparison to previously published Zn-isotope data from carbonates, but does mean there is potential for contamination. In ferromanganese crusts, $\mathrm{Zn}$ is relatively abundant and isotopically heavier $(\sim+0.5 \%$ ) than deep-ocean compositions (Little et al., 2014a). $\mathrm{Zn}$ in ferromanganese crusts is predominantly associated with birnessite $\left(\delta-\mathrm{MnO}_{2}\right)$, so $\mathrm{Mn}$ abundances of the leachates may be used to address possible contamination (Little et al., 2014b). These data imply that $\mathrm{Zn}$ derived from ferromanganese coatings does not have a significant impact on the $\mathrm{Zn} / \mathrm{Ca}$ and $\delta^{66} \mathrm{Zn}$ data presented here.

Firstly, $\mathrm{Mn} / \mathrm{Ca}$ values found for the leachates in this study are comparable to those presented by Clarkson et al. (2018) who present Mn/Ca on the same Raia del Pedale and Eastbourne sample sets and do include a reductive cleaning step prior to carbonate dissolution. Their data imply that the large majority of Mn (and by 
inference $\mathrm{Zn}$ ) present in the leachates from this study is associated with the carbonate phase rather than derived from ferromanganese coatings.

Secondly, stratigraphic $\mathrm{Mn} / \mathrm{Ca}$ patterns vary independently of $\delta^{66} \mathrm{Zn}$ and $\mathrm{Zn} / \mathrm{Ca}$, and stratigraphic $\mathrm{Zn} / \mathrm{Ca}$ patterns are comparable to $\mathrm{Zn} / \mathrm{Mn}$ data (Figure 2). Together, these observations suggest that varying contributions of $\mathrm{Zn}$ from ferromanganese coatings do not dominate stratigraphic patterns.

Finally, the lowest $\mathrm{Zn} / \mathrm{Mn}$ values found are $\sim 0.0052$ and $0.0088 \mathrm{~mol} / \mathrm{mol}$ for the Eastbourne and Barranca el Canon sections, respectively, which is higher than the $\sim 0.0025 \mathrm{~mol} / \mathrm{mol}$ found for average ferromanganese crusts (Little et al., 2014a). Assuming average ferromanganese crust composition for ferromanganese coatings in these carbonates, this suggests that, if all $\mathrm{Mn}$ in the leachates were derived from ferromanganese coatings, a maximum of $48 \%$ of total $\mathrm{Zn}$ would be derived from ferromanganese coatings. However, comparison with the Clarkson et al. (2018) data implies that most $\mathrm{Mn}$ is actually in the carbonate phase. The maximum proportion of $\mathrm{Zn}$ in the leachates presented here therefore is likely substantially lower than $48 \%$. Additionally, $\mathrm{Zn} / \mathrm{Ca}$ ratios in reductively cleaned foraminifera are comparable to or higher than values found for the carbonates in this study (Boyle, 1981).

\section{FIGURE CAPTIONS}

Figure $1 \mathrm{Zn} / \mathrm{Al}$ ratios, used to assess the amount of zinc leached from detrital phases. See text for discussion.

Figure $2 \mathrm{Mn} / \mathrm{Ca}$ ratios for the different sites. See text for discussion. 
Figure 3 Stratigraphic correlation of the three sections based on tying key inflection points from the published high-resolution carbon-isotope stratigraphies available for each location (Tsikos et al., 2004; Parente et al., 2008; Elrick et al 2009).

\section{REFERENCES CITED}

Archer, C., et al., 2017, Inter-calibration of a proposed new primary reference standard AA-ETH Zn for zinc isotopic analysis: Journal of Analytical Atomic Spectrometry, v. 32, p. 415-419, doi:10.1039/c6ja00282j.

Clarkson, M. O., Stirling, C. H., Jenkyns, H. C., Dickson, A. J., Porcelli, D., Moy, C. M., Pogge von Strandmann, P. A. E., Cooke, I. R, and Lenton, T. M., 2018, Uranium isotope evidence for two episodes of deoxygenation during Oceanic Anoxic Event 2: Proceedings of the National Academy of Sciences.

Elrick, M., Molina-Garza, R., Duncan, R., and Snow, L., 2009, C-isotope stratigraphy and paleoenvironmental changes across OAE2 (mid-Cretaceous) from shallowwater platform carbonates of southern Mexico: Earth and Planetary Science Letters, v. 277, p. 295-306, doi:10.1016/j.eps1.2008.10.020.

Kunzmann, M., Halverson, G. P., Sossi, P. A., Raub, T. D., Payne, J. L., and Kirby, J., 2013, Zn isotope evidence for immediate resumption of primary productivity after snowball Earth: Geology, v. 41, p. 27-30, doi:10.1130/G33422.1. 
Liu, S.-A., Wu, H., Shen, S.-Z., Jiang, G., Zhang, S., Lv, Y., Zhang, H., and Li, S., 2017, Zinc isotope evidence for intensive magmatism immediately before the end-Permian mass extinction: Geology, v. 45, p. 343-346, doi:10.1130/G38644.1.

Little, S., Vance, D., Walker-Brown, C., and Landing, W., 2014a, The oceanic mass balance of copper and zinc isotopes, investigated by analysis of their inputs, and outputs to ferromanganese oxide sediments: Geochimica et Cosmochimica Acta, v. 125, p. 673-693, doi:10.1016/j.gca.2013.07.046.

Little, S., Sherman, D.M., Vance, D., and Hein, J.R., 2014b, Molecular controls on $\mathrm{Cu}$ and $\mathrm{Zn}$ isotopic fractionation in Fe-Mn crusts: Earth and Planetary Science Letters, v. 396, p 213-222.

Moeller, K., Schoenberg, R., Pedersen, R. B., Weiss, D., and Dong, S., 2012, Calibration of the New Certified Reference Materials ERM-AE633 and ERMAE647 for Copper and IRMM-3702 for Zinc Isotope Amount Ratio Determinations: Geostandards and Geoanalytical Research, v. 36, p. 177-199, doi:10.1111/j.1751-908X.2011.00153.x.

Parente, M., Frijia, G., Di Lucia, M., Jenkyns, H. C., Woodfine, R. G., and Baroncini, F., 2008, Stepwise extinction of larger foraminifers at the Cenomanian-Turonian boundary: A shallow-water perspective on nutrient fluctuations during Oceanic Anoxic Event 2 (Bonarelli Event): Geology, v. 36, p. 715-718, doi: 10.1130/G24893A.1. 
Pichat, S., Douchet, C., and Albarède, F., 2003, Zinc isotope variations in deep-sea carbonates from the eastern equatorial Pacific over the last $175 \mathrm{ka}$ : Earth and Planetary Science Letters, v. 210, p. 167-178, doi:10.1016/S0012821X(03)00106-7.

Rudge, J. F., Reynolds, B. C., and Bourdon, B., 2009, The double spike toolbox: Chemical Geology, v. 265, p. 420-431, doi:10.1016/j.chemgeo.2009.05.010.

Rudnick, R.L., and Gao, S., 2003, Composition of the continental crust:, Treatise on Geochemistry, v. 3, p. 1-64, doi: 10.1016/B0-08-043751-6/03016-4.

Tessier, A., Campbell, P. G., and Bisson, M., 1979, Sequential extraction procedure for the speciation of particulate trace metals: Analytical Chemistry, v. 51, p. 844851.

Tsikos, H., Jenkyns, H., Walsworth-Bell, B., Petrizzo, M., Forster, A., Kolonic, S., Erba, E., Silva, I. P., Baas, M., and Wagner, T., 2004, Carbon-isotope stratigraphy recorded by the Cenomanian-Turonian Oceanic Anoxic Event: correlation and implications based on three key localities: Journal of the Geological Society, v. 161, p. 711-719, doi:10.1144/0016-764903-077. 


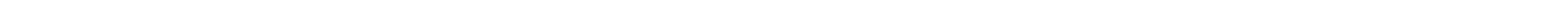



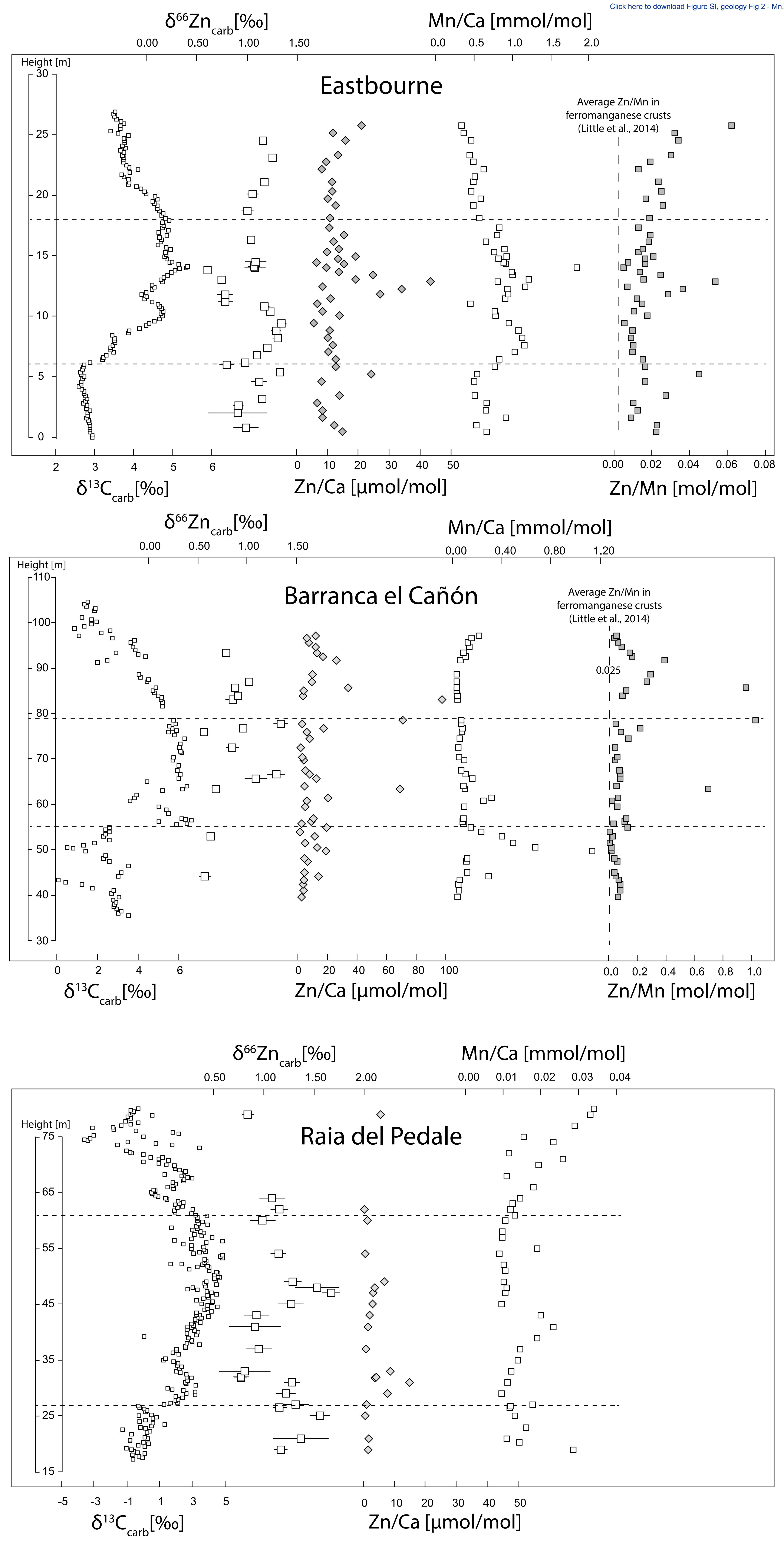


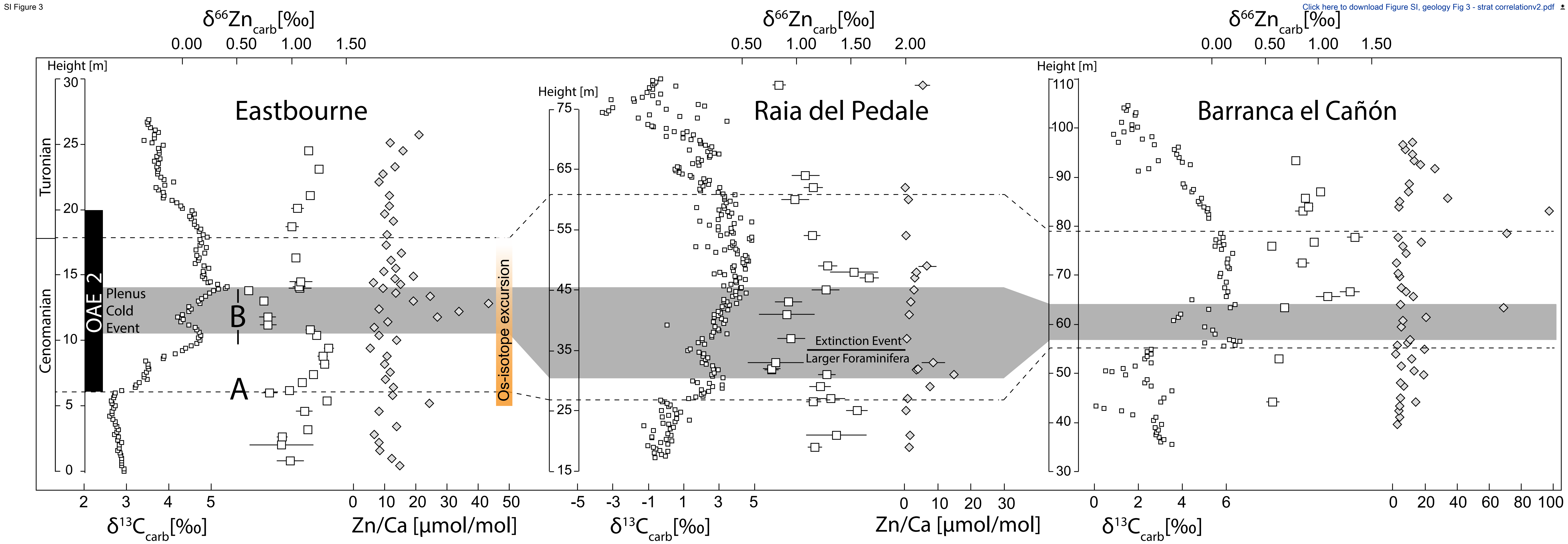


Eastbourne

$\begin{array}{ccc}\text { Height }[\mathrm{m}] & \mathbf{d} 66 / 64 \mathrm{Zn} & \text { 2 s.e. } \\ 0.8 & 0.99 & 0.13 \\ 2 & 0.91 & 0.29 \\ 2.6 & 0.91 & 0.05 \\ 3.2 & 1.15 & 0.03 \\ 4.6 & 1.12 & 0.08 \\ 5.4 & 1.32 & 0.01 \\ 6 & 0.80 & 0.07 \\ 6.2 & 0.98 & 0.03 \\ 6.8 & 1.10 & 0.03 \\ 7.4 & 1.20 & 0.01 \\ 8.2 & 1.30 & 0.05 \\ 8.8 & 1.28 & 0.05 \\ 9.4 & 1.34 & 0.05 \\ 10.4 & 1.23 & 0.03 \\ 10.8 & 1.17 & 0.05 \\ 11.2 & 0.79 & 0.08 \\ 11.8 & 0.78 & 0.08 \\ 13 & 0.74 & 0.02 \\ 13.8 & 0.61 & 0.02 \\ 14 & 1.08 & 0.10 \\ 14.1 & 1.07 & 0.06 \\ 14.5 & 1.09 & 0.10 \\ 16.3 & 1.04 & 0.00 \\ 18.7 & 1.01 & 0.06 \\ 20.1 & 1.05 & 0.06 \\ 21.1 & 1.17 & 0.00 \\ 23.1 & 1.25 & 0.00 \\ 24.5 & 1.15 & 0.00\end{array}$

BC (Mexico)

Height [m] Eastbourne height equivalent $\mathrm{d} 66 / 64 \mathrm{Zn} 2$ s.e.

$\begin{array}{cccc}44.2 & 2.37 & 0.57 & 0.06 \\ 53 & 5.45 & 0.63 & 0.03 \\ 63.4 & 13.59 & 0.68 & 0.04 \\ 65.6 & 14.59 & 1.09 & 0.12 \\ 66.6 & 14.97 & 1.29 & 0.09 \\ 72.5 & 17.16 & 0.85 & 0.07 \\ 75.9 & 18.12 & 0.56 & 0.03 \\ 76.8 & 18.26 & 0.96 & 0.03 \\ 77.8 & 18.42 & 1.34 & 0.08 \\ 83.1 & 19.26 & 0.85 & 0.08 \\ 84 & 19.41 & 0.91 & 0.04 \\ 85.7 & 19.68 & 0.88 & 0.04 \\ 87 & 19.88 & 1.02 & 0.03 \\ 93.3 & 20.88 & 0.78 & 0.04\end{array}$


Raia del Pedale

Height $[\mathrm{m}]$ Eastbourne height equivalent $\mathrm{d} 66 / 64 \mathrm{Zn} 2 \mathrm{2}$ s.e.

$\begin{array}{cccc}19 & -0.29 & 1.17 & 0.06 \\ 21 & 1.39 & 1.36 & 0.28 \\ 25 & 4.74 & 1.55 & 0.10 \\ 26.5 & 6.00 & 1.16 & 0.07 \\ 27 & 6.42 & 1.31 & 0.13 \\ 29 & 8.10 & 1.22 & 0.10 \\ 31 & 9.77 & 1.28 & 0.08 \\ 31.75 & 10.40 & 0.77 & 0.07 \\ 32 & 10.50 & 0.78 & 0.08 \\ 33 & 10.90 & 0.81 & 0.26 \\ 37 & 12.14 & 0.95 & 0.13 \\ 41 & 12.92 & 0.91 & 0.26 \\ 43 & 13.32 & 0.93 & 0.13 \\ 45 & 13.71 & 1.27 & 0.13 \\ 47 & 14.14 & 1.67 & 0.09 \\ 48 & 14.43 & 1.53 & 0.22 \\ 49 & 14.72 & 1.29 & 0.09 \\ 54 & 16.17 & 1.14 & 0.08 \\ 60 & 17.90 & 0.99 & 0.13 \\ 62 & 18.48 & 1.16 & 0.09 \\ 64 & 19.06 & 1.08 & 0.13 \\ 79 & 23.39 & 0.84 & 0.06\end{array}$


Eastbourne

Height [m] $\mathrm{Zn} / \mathrm{Ca}[\mathrm{umol} / \mathrm{mol}] \mathrm{Al} / \mathrm{Ca}[\mathrm{umol} / \mathrm{mol}] \mathrm{Mn} / \mathrm{Ca}[\mathrm{mmol} / \mathrm{mol}]$

$\begin{array}{llll}0.40 & 14.87 & 6.95 & 0.6665 \\ 1.00 & 12.30 & 4.67 & 0.5364 \\ 1.60 & 8.44 & 8.47 & 0.9134\end{array}$

$\begin{array}{llll}1.60 & 8.44 & 8.47 & 0.9134 \\ 2.20 & 8.36 & 5.78 & 0.6599\end{array}$

$\begin{array}{llll}2.80 & 6.79 & 7.86 & 0.6697\end{array}$

$\begin{array}{llll}3.40 & 13.95 & 8.43 & 0.5085\end{array}$

$\begin{array}{llll}4.60 & 8.31 & 8.57 & 0.5049\end{array}$

$\begin{array}{llll}5.20 & 24.32 & 13.97 & 0.5387\end{array}$

$\begin{array}{llll}5.80 & 12.77 & 17.30 & 0.7749\end{array}$

$\begin{array}{llll}6.40 & 12.78 & 13.39 & 0.8329\end{array}$

$\begin{array}{llll}7.00 & 10.23 & 20.94 & 1.0344\end{array}$

$\begin{array}{llll}7.60 & 11.80 & 15.84 & 1.1541\end{array}$

$\begin{array}{llll}8.20 & 10.21 & 24.56 & 1.1302\end{array}$

$\begin{array}{llll}8.80 & 10.77 & 20.40 & 1.0850\end{array}$

$\begin{array}{llll}9.40 & 5.49 & 21.29 & 0.9526\end{array}$

$\begin{array}{llll}10.00 & 13.82 & 10.12 & 0.7818\end{array}$

$\begin{array}{llll}10.40 & 8.36 & 11.30 & 0.7743\end{array}$

$11.00 \quad 6.73$

$11.40 \quad 11.02$

$11.80 \quad 27.09$

$12.20 \quad 33.99$

$12.40 \quad 8.32$

$12.80 \quad 43.40$

$13.00 \quad 19.20$

$13.40 \quad 24.65$

$13.60 \quad 13.68$

$14.00 \quad 9.63$

$14.30 \quad 15.26$

$14.40 \quad 6.57$

$14.70 \quad 13.45$

$14.90 \quad 19.29$

$15.30 \quad 9.78$

$15.50 \quad 13.78$

$16.10 \quad 12.08$

$16.70 \quad 15.41$

$17.30 \quad 10.62$

$18.10 \quad 10.79$

$19.10 \quad 12.78$

$19.70 \quad 9.99$

$20.30 \quad 11.66$

$21.10 \quad 11.59$

$21.50 \quad 68.82$

$22.10 \quad 8.21$

$22.70 \quad 9.65$

$23.30 \quad 13.37$

$24.50 \quad 15.94$

$25.10 \quad 11.82$

$25.70 \quad 21.18$
$4.32 \quad 0.4525$

$18.62 \quad 0.9125$

$14.47 \quad 0.9386$

$5.71 \quad 1.1670$

$42.81 \quad 0.8125$

$8.50 \quad 1.2194$

$13.35 \quad 1.0012$

$8.36 \quad 0.9951$

$4.79 \quad 1.8404$

$4.96 \quad 0.9173$

$8.57 \quad 0.8904$

$4.07 \quad 0.8217$

$5.96 \quad 0.9257$

$4.68 \quad 0.7612$

$5.21 \quad 0.8979$

$5.39 \quad 0.6568$

$4.71 \quad 0.8041$

$5.09 \quad 0.8274$

$4.25 \quad 0.5690$

$3.14 \quad 0.4962$

$3.17 \quad 0.5947$

$5.38 \quad 0.4630$

$6.58 \quad 0.4950$

$36.78 \quad 0.5139$

$8.32 \quad 0.6258$

$5.31 \quad 0.4968$

$4.94 \quad 0.4428$

$7.63 \quad 0.4679$

$4.95 \quad 0.3680$

$8.67 \quad 0.3400$
$14.58 \quad 0.9430$

$\underline{B C}($

Height [m] Eastbourne height equivalent [m]

\begin{tabular}{|c|c|}
\hline 39.60 & 0.76 \\
\hline 41.10 & 1.29 \\
\hline 42.30 & 1.71 \\
\hline 43.40 & 2.09 \\
\hline 44.20 & 2.37 \\
\hline 45.00 & 2.65 \\
\hline 47.50 & 3.53 \\
\hline 48.00 & 3.70 \\
\hline 49.70 & 4.30 \\
\hline 50.60 & 4.61 \\
\hline 51.50 & 4.93 \\
\hline 53.00 & 5.45 \\
\hline 54.00 & 5.60 \\
\hline 55.00 & 7.45 \\
\hline 55.80 & 8.92 \\
\hline 56.20 & 9.66 \\
\hline 56.90 & 10.50 \\
\hline 59.50 & 11.37 \\
\hline 60.80 & 11.80 \\
\hline 61.50 & 12.28 \\
\hline 63.40 & 13.59 \\
\hline 64.00 & 14.00 \\
\hline 65.60 & 14.59 \\
\hline 66.60 & 14.97 \\
\hline 67.50 & 15.30 \\
\hline 69.70 & 16.12 \\
\hline 70.40 & 16.38 \\
\hline 72.50 & 17.16 \\
\hline 74.50 & 17.90 \\
\hline 75.90 & 18.12 \\
\hline 76.80 & 18.26 \\
\hline 77.80 & 18.42 \\
\hline 78.50 & 18.53 \\
\hline 83.10 & 19.26 \\
\hline 84.00 & 19.41 \\
\hline 85.00 & 19.57 \\
\hline 85.70 & 19.68 \\
\hline 87.00 & 19.88 \\
\hline 88.70 & 20.15 \\
\hline 91.80 & 20.64 \\
\hline 92.50 & 20.75 \\
\hline 93.30 & 20.88 \\
\hline 94.70 & 21.10 \\
\hline 95.70 & 21.26 \\
\hline 96.70 & 21.42 \\
\hline 97.20 & 21.50 \\
\hline
\end{tabular}


Mexico)

$\mathrm{Zn} / \mathrm{Ca}[\mathrm{umol} / \mathrm{mol}] \mathrm{Al} / \mathrm{Ca}[\mathrm{umol} / \mathrm{mol}] / \mathrm{Ca}[\mathrm{mmol} / \mathrm{mol}]$

$\begin{array}{lll}2.59 & 2.86 & 0.04 \\ 4.42 & 2.83 & 0.05\end{array}$

$\begin{array}{lll}3.61 & 3.29 & 0.04\end{array}$

$\begin{array}{lll}4.23 & 3.15 & 0.06\end{array}$

$\begin{array}{lll}14.12 & 90.75 & 0.30\end{array}$

$\begin{array}{lll}4.90 & 25.15 & 0.12\end{array}$

$\begin{array}{lll}7.02 & 9.52 & 0.11\end{array}$

$\begin{array}{lll}4.70 & 6.23 & 0.12\end{array}$

$\begin{array}{lll}19.22 & 294.51 & 1.14\end{array}$

$\begin{array}{lll}13.23 & 134.50 & 0.67\end{array}$

$\begin{array}{lll}5.50 & 26.95 & 0.49\end{array}$

$\begin{array}{lll}11.93 & 33.94 & 0.40\end{array}$

$\begin{array}{lll}2.04 & 5.89 & 0.23\end{array}$

$\begin{array}{lll}19.89 & 6.30 & 0.15\end{array}$

$\begin{array}{lll}3.02 & 27.87 & 0.09\end{array}$

$\begin{array}{lll}9.41 & 26.64 & 0.08\end{array}$

$\begin{array}{lll}10.83 & 26.74 & 0.09\end{array}$

$5.55 \quad 2.68$

$6.49 \quad 23.25$

$\begin{array}{rr}6.98 & 33.21 \\ 68.97 & 6.17\end{array}$

68.97

4.99

12.71

8.18

5.30

4.31

3.30

2.16

8.28

6.37

17.84

3.41

70.99

97.39

3.72

4.53

34.15

9.83

10.23

26.22

17.14

13.45

12.37

7.91

6.47

12.08
3.42

15.20

10.29

5.71

8.74

9.97

2.23

3.39

5.73

32.47

4.99

14.32

8.42

3.66

3.60

3.97

3.47

2.15

58.87

6.97

24.15

5.38

6.82

3.93

69.56

Raia del Pedale

Height [m] Eastbourne height equivalent [m] Zn [umol/mol]

2 s.e.

$\begin{array}{lrrr}19.00 & -0.29 & 1.51 & 0.60 \\ 21.00 & 1.39 & 1.79 & \\ 25.00 & 4.74 & 0.53 & 0.21 \\ 27.00 & 6.42 & 1.04 & 0.42 \\ 29.00 & 8.10 & 7.75 & \\ 31.00 & 9.77 & 14.81 & \\ 31.75 & 10.40 & 3.75 & \\ 32.00 & 10.50 & 4.11 & \\ 33.00 & 10.90 & 8.67 & 3.47 \\ 37.00 & 12.14 & 0.88 & 0.35 \\ 41.00 & 12.92 & 1.39 & 0.56 \\ 43.00 & 13.32 & 1.92 & 0.77 \\ 45.00 & 13.71 & 3.02 & 1.21 \\ 47.00 & 14.14 & 3.17 & 1.27 \\ 48.00 & 14.43 & 3.64 & \\ 49.00 & 14.72 & 6.86 & 2.75 \\ 54.00 & 16.17 & 0.47 & 0.19 \\ 60.00 & 17.90 & 1.24 & 0.50 \\ 62.00 & 18.48 & 0.36 & 0.15 \\ 79.00 & 23.39 & 5.64 & 2.26\end{array}$


Height (m) Mn/ca [mmol $/ \mathrm{mol}]$

$\begin{array}{ll}19 & 0.028577386\end{array}$

$20.25 \quad 0.014308717$

$21 \quad 0.011048051$

$23 \quad 0.015998819$

$25 \quad 0.013119209$

$26.5 \quad 0.011710924$

$26.5 \quad 0.011803042$

$26.75 \quad 0.011869314$

$27 \quad 0.017747641$

$29 \quad 0.009552367$

$31 \quad 0.01108791$

$33 \quad 0.012132457$

$35 \quad 0.013984213$

$37 \quad 0.014528182$

$39 \quad 0.019061035$

$41 \quad 0.023178392$

$43 \quad 0.019874931$

$45 \quad 0.00963873$

$47 \quad 0.010578457$

$48 \quad 0.011029387$

$49 \quad 0.010295044$

$51 \quad 0.01049557$

$52 \quad 0.010151806$

$54 \quad 0.008945039$

$55 \quad 0.018921778$

$57 \quad 0.009860267$

$58 \quad 0.009732214$

$60 \quad 0.010634712$

$61 \quad 0.013067966$

$62 \quad 0.011920156$

$63 \quad 0.012504713$

$64 \quad 0.014502171$

$66 \quad 0.018056854$

$68 \quad 0.0109351$

$70 \quad 0.019450218$

$71 \quad 0.025798882$

$72 \quad 0.011660729$

$74 \quad 0.023363286$

$75 \quad 0.015561623$

$77 \quad 0.028921983$

$79 \quad 0.033060769$

$80 \quad 0.03402227$ 